Article

\title{
Boom, Bust and Beyond: Arts and Sustainability in Calumet, Michigan
}

\author{
Richelle Winkler ${ }^{1, *, \dagger}$, Lorri Oikarinen ${ }^{2,+}{ }^{,}$Heather Simpson ${ }^{3}$, Melissa Michaelson ${ }^{1}$ \\ and Mayra Sanchez Gonzalez ${ }^{4}$ \\ 1 Department of Social Sciences, Michigan Technological University, Houghton, MI 49931, USA; \\ mmwolfem@mtu.edu \\ 2 Calumet, MI 49913, USA; lorri@crosscountrysports.com \\ 3 Center for Student Success, Michigan Technological University, Houghton, MI 49931, USA; \\ hsimpson@mtu.edu \\ 4 Environmental and Energy Policy Program, Michigan Technological University, Houghton, MI 49931, USA; \\ mosanche@mtu.edu \\ * Correspondence: rwinkler@mtu.edu; Tel.: +1-906-487-1886 \\ + These authors contributed equally to this work.
}

Academic Editor: Tan Yigitcanlar

Received: 4 January 2016; Accepted: 11 March 2016; Published: 21 March 2016

\begin{abstract}
Cycles of boom and bust plague mining communities around the globe, and decades after the bust the skeletons of shrunken cities remain. This article evaluates strategies for how former mining communities cope and strive for sustainability in the decades well beyond the bust, using a case study of Calumet, Michigan. In 1910, Calumet was at the center of the mining industry in the Upper Peninsula of Michigan, but in the century since its peak, mining employment steadily declined until the last mine closed in 1968, and the population declined by over $80 \%$. This paper explores challenges, opportunities, and progress toward sustainability associated with arts-related development in this context. Methods are mixed, including observation, interviews, document review, a survey, and secondary data analysis. We follow Flora and Flora's Community Capitals Framework to analyze progress toward sustainability. Despite key challenges associated with the shrunken city context (degraded tax base, overbuilt and aging infrastructure, diminished human capital, and a rather limited set of volunteers and political actors), we find the shrunken city also offers advantages for arts development, including low rents, less risk of gentrification, access to space, and political incentive. In Calumet, we see evidence of a spiraling up pattern toward social sustainability resulting from arts development; however impacts on environmental and economic sustainability are limited.
\end{abstract}

Keywords: art; mining; boom and bust; community development; social capital; infrastructure; tax base; community identity

\section{Introduction}

For decades, the dominant narrative on mining and community development has been of "boom and bust". From the Gold Rush of the nineteenth century to the "boom" following the 1970s oil crisis, to the more recent gas boom in areas of the Great Plains; communities boom as mining interests develop, grow a related workforce, populations increase, and spillover businesses are created. They then "bust" as technology replaces workers, ore bodies are mined out, markets change, jobs are lost, environments get contaminated, and people move away [1]. In fact, mining has a reputation of being an inherently unsustainable industry [2].

During and after the bust, former mining communities tend to suffer from high poverty rates and unemployment, population decline, decaying infrastructure, political acquiescence, and environmental 
contamination [2-13]. Many mining towns eventually become ghost towns, and many more stand as prime examples of urban decline.

This paper focuses on what happens beyond the boom and bust and draws implications for sustainable development initiatives in former mining communities and other "shrunken" cities in relatively remote locations. The key purpose of the study is to analyze opportunities for arts-related development projects to serve as a catalyst for former mining communities to create sustainable futures. We do this using a case study of Calumet, Michigan in the heart of the former copper mining district in Michigan's Upper Peninsula.

We define sustainability broadly, following the three pillars of social, economic, and environmental sustainability as put forth at the 2002 World Summit on Sustainable Development in the Johannesburg Declaration [14]. More specifically, we conceptualize sustainability by employing Flora and Flora's Community Capitals Framework (CCF) [15] which sets forth seven dimensions of community sustainability (natural, cultural, financial, social, built, human, and political). The CCF includes components that address each of the three pillars, with more of a focus on the complexities of social sustainability (including cultural, social, human, political, and built capital dimensions). It also includes attention to environmental sustainability (natural capital) and economic sustainability (financial capital). We employ Flora and Flora's Community Capitals Framework [15] and Emery and Flora's [16] spiraling model of community transformation to explore the challenges, opportunities, and progress toward the three pillars of sustainability associated with arts-related development. Throughout the paper, we focus on the shrunken city context and the unique conditions that impact the viability of sustainable community development strategies under the conditions of urban shrinkage.

Arts-related development strategies are increasingly common approaches to sustainable community development. Various art activities (ranging from formal museums, to art fairs and festivals, to less formal coffee shop and gallery spaces, to arts classes, mural painting, and street music) are increasingly seen as a potential engine for community and economic development [17]. The approach has been most popular in concentrated urban centers, but pockets of artists and arts-related development projects can also be found in several specific rural areas across the U.S. and Canada [18,19]. Arts attract people (residents and tourists) and businesses [19,20], empower community members to express themselves and gain political voice [21], promote both bridging and bonding social capital [22], and can help to regenerate communities [17,23].

Research shows that investment in the arts can have regenerative effects in older industrial cities $[24,25]$. Arts activities can facilitate the process of unique "place-making" (how a place is made and re-made) by tying together physical geography and the meaning and value of place [26]. Holland and Vail [26] refer to this process as "place imprinting" and recognize the role of the arts in shaping how we think about and understand particular places. In this way, art might be a venue through which old mining towns can reshape their identities toward sustainable futures.

At the same time, arts related development can pose challenges to socially inclusive sustainable community development including commodification of place, excluding disadvantaged populations, and residential gentrification [27-29]. These dangers are particularly troublesome in the context of an economically depressed and shrunken city where housing affordability is a saving grace for lower income residents. If arts development increases rents without a corresponding and sufficient increase in income among local residents, the overall impact on livelihoods may be negative. Keeping art public, accessible and inclusive are important strategies for maintaining socially inclusive development and spurring social capital [30] rather than a growth machine [31].

Using the Calumet case study, we identify three key sustainability challenges associated with the shrunken city context: a diminished tax base, overbuilt and aging infrastructure, and reduced human capital. These difficulties make any kind of revitalization effort more arduous, but they also shape the opportunity environment. In Calumet, this context is a large part of what has spurred arts re-development efforts forward. Overall, we find that arts based strategies are helping to revitalize Calumet's downtown, but they are not enough without effective programs to support low-income populations and additional investment in the basic infrastructure base. 


\section{Materials and Methods}

This paper is the result of a culmination of data, discussion, and interpretation generated through a three-year campus-community partnership between a professor and her students at a mid-sized university and Main Street Calumet, a grassroots community organization aimed at revitalizing the historic downtown district in Calumet, Michigan. A total of 27 students and dozens of community members have participated.

Courses in rural community sustainability and community-engaged research were offered in Spring 2013, Fall 2013, and Fall 2014. Each of these courses was organized around a particular research project that engaged an interdisciplinary set of undergraduate and graduate students and community members. The research projects were chosen by community members with the goal of better understanding and evaluating their own efforts and ideas for promoting sustainable community development in Calumet's downtown. All three projects used Flora and Flora's [15] Community Capitals Framework (described below) as a conceptual model for evaluating community sustainability. Data collected and analyzed during these courses (especially the course on arts in Spring 2013) form the basis of support for this paper. Additional interviews and secondary data were collected by the authors in 2015, as needed.

The project in Spring 2013 was focused around evaluating the impact of the arts on sustainable community development [32]. Data collected during that project serve as the basis of what is presented here. Projects in Fall 2013 and Fall 2014 explored the potential for tapping into water in abandoned mines beneath the community for geothermal energy. Data and analysis resulting from the minewater geothermal projects are incorporated in this study to understand community sustainability in a general sense and whenever they resulted in discussion of arts-related activities.

The research teams employed a variety of methods and a rich collection of triangulated data to explore the challenges, opportunities, and progress towards sustainability associated with the projects. Methods included: semi-structured interviews (see Supplementary Material A for protocols); targeted interviews with community leaders; direct and participant observation; a census and survey of art gallery visitors (see Supplementary Material B for survey); historical document review; and a variety of secondary data analysis from sources such as the US Census Bureau and local records. Altogether we conducted and transcribed 24 semi-structured interviews with community leaders and residents (10 of whom were directly involved in the arts community and 14 of whom who were not). The interviews inquired about personal community attachment and well-being, community well-being, and local arts activities. We conducted five targeted interviews with business-owners and community leaders. We also surveyed 368 visitors to Calumet's First Friday art events between February and April (winter) 2013, collecting data on age, gender, residence/travel distance, frequency of attendance, reasons for attendance, and community observations. The team spent over $500 \mathrm{~h}$ in the field and regularly compiled associated observation notes. The interview transcriptions, observation notes, and open ended survey responses were all thematically coded with attention to Flora and Flora's seven dimensions of community sustainability (Community Capitals). Coding was done both individually and jointly to ensure consistency. The team worked collaboratively to draw interpretations and conclusions, challenging one another to support claims with consistent evidence from multiple sources.

In all, our research team amassed a rich set of data and a level of interpretation that proved consistent across multiple perspectives and voices from students, faculty, and community members. The data and interpretations presented in this paper are the culmination of these broader efforts. Throughout the paper, when we present data for "Calumet" we do so referring to the Calumet township boundaries, which includes the Village of Calumet, Village of Laurium, and Calumet Township. We refer to the Village of Calumet specifically, at times, as the "downtown core".

\subsection{Community Capitals Framework}

The Community Capitals Framework [15] considers seven assets (or "capitals") that communities need to balance to create healthy, sustainable, and socially inclusive communities. These capitals 
are natural, cultural, human, social, political, financial, and built. Together, they capture the multidimensional nature of a sustainable community (as shown in Figure 1). The Community Capitals Framework (CCF) provides a well-developed, scientifically and conceptually sound tool to assess a community's existing assets and how they change in response to specific community based efforts [33].

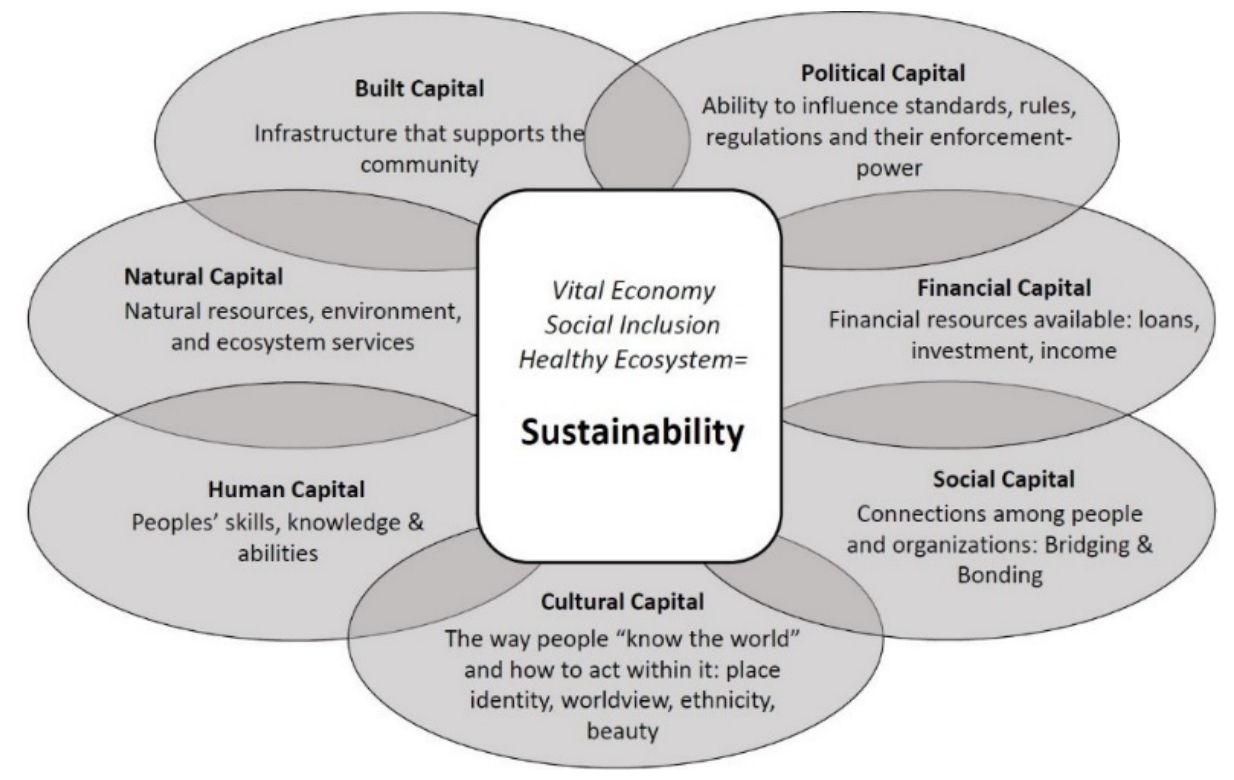

Figure 1. Figure defines each of Flora and Flora's Community Capitals. When balanced, these capitals contribute to a vital economy, social inclusion, and a healthy ecosystem. We use this framework for measuring and evaluating sustainability. The figure is modified from a similar figure shown in Flora and Flora [15].

Using the CCF as its base, Emery and Flora [16] present a theoretical model of how the seven capitals are related to processes of community change. This "spiraling model" takes a systems perspective to look for community resources and processes that contribute to either a "downward spiral of loss" or an "upward spiral of hope". The model recognizes that loss of industry can lead to a spiral of decline which "makes it more difficult to mobilize political capital, which stimulates additional losses in human and social capitals in a vicious cycle of despair" [16]. More optimistically, the model also assumes that smart and balanced investment in any or all of the community capitals (especially in social capital) could offer increased resources and motivation to spur additional program development progressively building upon successes to generate a "spiraling up" process.

Figure 2 illustrates one pattern of how the spiraling model has worked historically in the case community (Calumet). On the right side, it shows how initial investments in natural, social, financial, and built capital associated with copper mining in the late nineteenth century led to a spiraling up process of community growth. This particular process was not sustainable, at least in part because investment into each of the seven capitals was not balanced with natural, human, and political capital being exploited and eventually depleted. The subsequent "spiraling down" is shown on the left side as mining employed ever fewer people and eventually closed, which led to disinvestment in other community capitals and gradually to the community's shrinkage. 

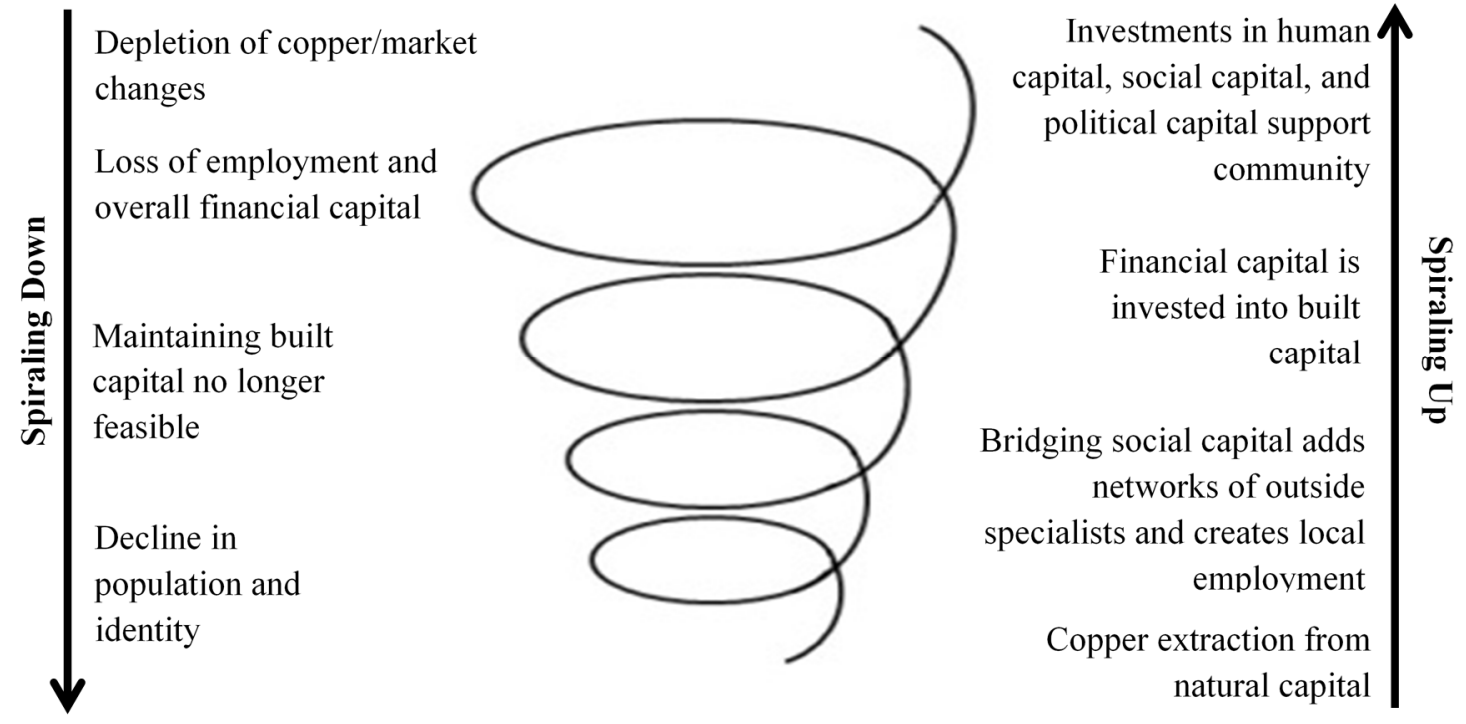

Figure 2. Figure demonstrates the process of "spiraling up" or "spiraling down" described in Emery and Flora's [16] conception of how investment or disinvestment in community capitals can impact community sustainability. This figure is a modified version of a similar figure shown in Emery and Flora [16].

\subsection{The Case: Calumet, Michigan}

Calumet is located in the western part of Michigan's Upper Peninsula (see Figure 3). It is a small community of about 6500 residents in the local area and 726 residents in the core downtown. The nearest larger communities are the twin cities of Hancock and Houghton about 15 miles to the south, which together with Michigan Technological University students have a combined population of about 20,000 residents. The nearest metropolitan area is Green Bay, Wisconsin, about 225 miles to the south on mostly two-lane roads. Calumet's downtown is a National Historic Landmark District and is within the boundaries of the Keweenaw National Historical Park.

Calumet is located about five miles from the Lake Superior shore, on the Keweenaw Peninsula. The land is heavily forested, with primarily deciduous but also a mix of conifer and hardwood forest (authors' calculations based on the National Land Cover Database 2011 [34]). The Keweenaw Fault runs through this area which results in topological variation in the immediate Calumet vicinity ranging from about 500-1300 ft above sea level. The area experiences long, cold winters with some of the heaviest snowfalls in the United States and short mild summers.

At the turn of the twentieth century, Calumet was at the center of a booming copper mining industry and had a population of about 33,000 in what was then known as the village of "Red Jacket" and the immediately surrounding area. In 1913-1914, Red Jacket was at the center of a bitter labor strike which gained national attention and forever changed its history. On 24 December 1913, the town was the site of a tragic event which became known as the Italian Hall Disaster. Striking miners and their families were gathered in the upper floor of the Italian Hall for a Christmas party when a false cry of "fire" led to a stampede in which 73 people, mostly children, were smothered in the stairway. The controversy of who cried fire has never been resolved; but the tragedy, failed strike, and related changes in mining technology and working conditions led to the first exodus of population out of the area with thousands leaving to work in the emerging automobile industry in Detroit which paid higher wages for safer work [35]. 


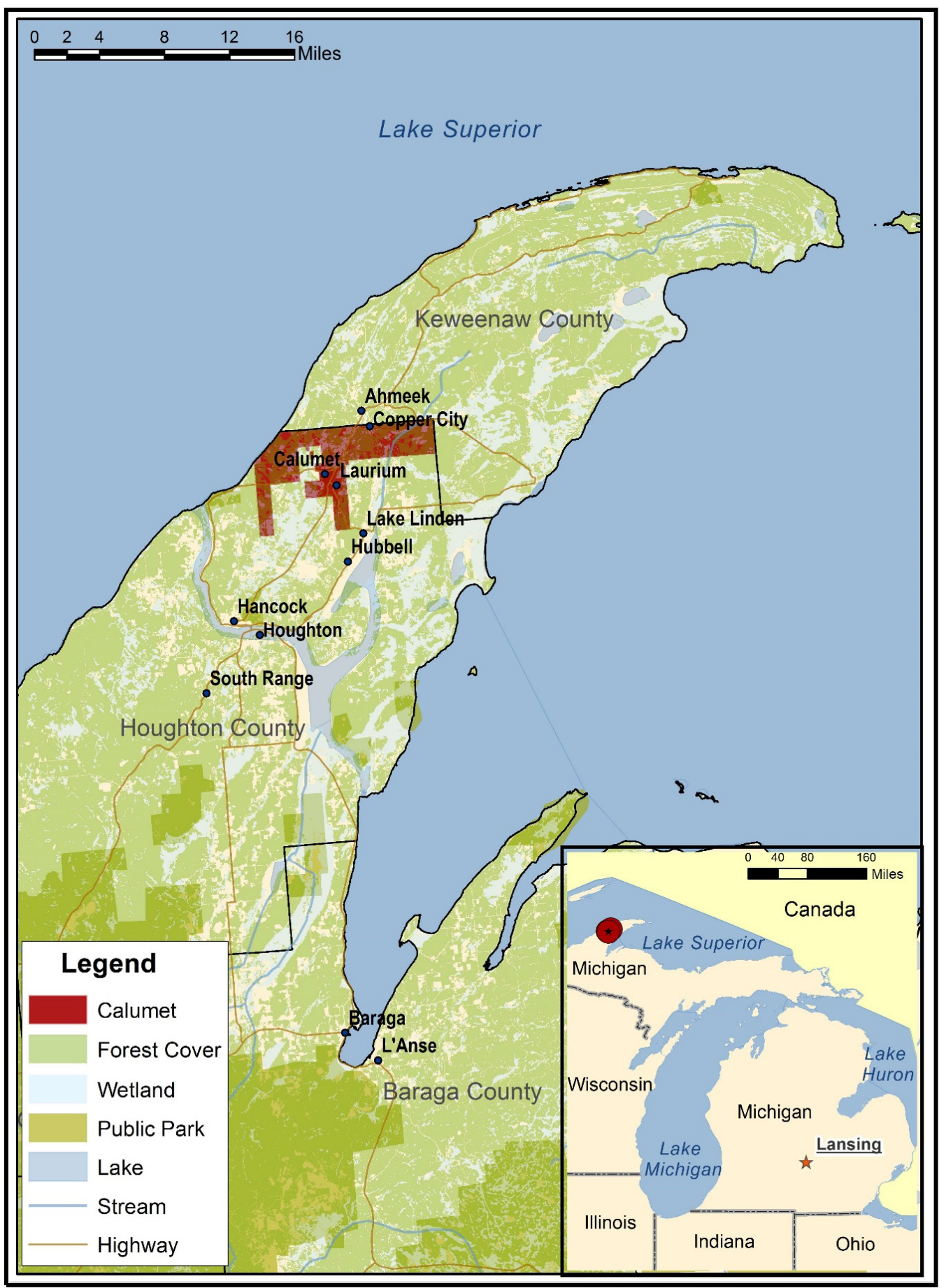

Figure 3. Map of the Calumet, Michigan area. Data Sources: US Census Bureau TIGER/Line shapefiles [36]; ESRI Data and Maps for ArcMap 10.1 [37]; National Land Cover Database 2011 [34]. Coordinate System: Albers.

After World War I, the demand for copper decreased and thousands more left the area in the 1920s. The Great Depression saw most of the mines close and more people left to find jobs elsewhere, particularly in Detroit [35]. By 1950, the Calumet area population had shrunk by two-thirds to about 10,000. Mining continued on a smaller scale, particularly during WWII, until declining demand for copper after World War II and a labor strike in 1968 closed the mines permanently [35]. By 2010, the 
population of the core Village of Calumet had shrunk to 726, and surrounding Calumet Township to around 6500 residents (see Figure 4).

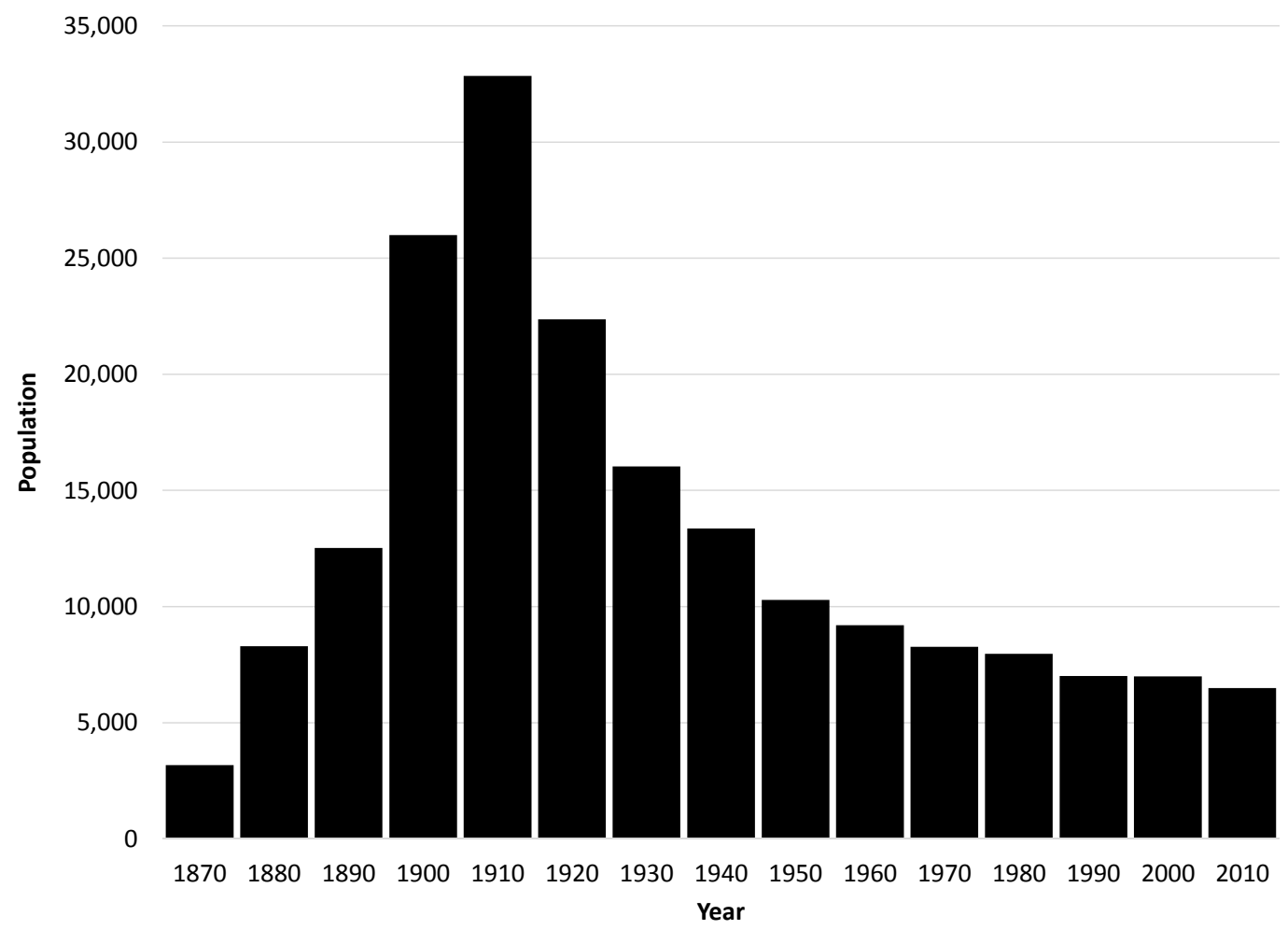

Figure 4. Figure shows population change in Calumet Township, Michigan 1870-2010, as recorded by the US Census Bureau and accessed via NHGIS [38].

Calumet grew up and was built around copper mining. The Calumet and Hecla Mining Company (C \& H) (Jasper, AL, USA) was the area's largest employer and the leading copper producer in the world in the late nineteenth century. Copper mining created a variety of employment opportunities and financial capital which opened up further opportunities to create infrastructure and to invest in human, social and cultural capitals. C \& $\mathrm{H}$ was well known for its paternalistic practices of investing in community infrastructure and providing for worker's needs, but these provisions were conditioned by continued employment with the company and by the company maintaining success [35]. When mining operations slowed down and eventually shut down, C \& H left the community. Community social and economic investment, much of which had been supplied by $\mathrm{C} \& \mathrm{H}$, began to decline and change [35]. The consequence of gradually losing the industry was a dramatic decline in financial capital which then contributed to a loss of employment, people, and the resources to maintain the community's infrastructure.

In the last two decades, Calumet has started to show evidence of a gradual shift toward a more sustainable future. Three key initiatives have been supporting this shift, including: (1) efforts to support and celebrate the community's historical legacy through the creation of the Keweenaw National Historical Park; (2) supplying and promoting outdoor recreation opportunities and nature-based tourism; and (3) through arts-related downtown development. Since the early 2000s, artists and businesspeople have created an arts district in downtown Calumet which now includes three traditional galleries, an art center, a sculpture park, the Calumet Theater (a historic and continually operating performance hall), and seven other shops/studios/cafes that regularly show art. In 2004, local artists started a First Friday's art walk which has gradually grown and continues to take place in the downtown arts district the first Friday of every month. The art scene in Calumet is continuing to grow with increasing participation and cooperation among at least 10 different art spaces. 


\section{Results}

\subsection{Participation in the Arts}

According to the American Community Survey (2010-2014), about 65 people (2.5\% of the workforce) gain their primary employment in the arts, entertainment, and recreation industry which is up from about 26 people (1\% of workforce) in 2000. Other artists do the work as a secondary occupation or hobby, and in total about 80 different local artists exhibit work in Calumet's art spaces. For a community of only 726 people in the downtown core and about 6500 in the broader community, this is a fairly substantial number.

Beyond the artists themselves, a critical mass of people attend First Fridays and show interest in engaging in the art scene in Calumet. The research team surveyed 368 unique visitors to eight art spaces on First Fridays in February, March, and April of 2013. A typical First Friday in early 2013 brought 100-200 visitors. Again, this is a substantial number, given the relatively small population of the community and in the surrounding region. Counting the same people more than once at different art spaces and in different months, we observed a total of 1077 total visits to art spaces in these three First Fridays. Arts district visitors (average age 48 years) were older than the Calumet area population as a whole (40 years), and females were somewhat overrepresented (55\%). About a third of visitors came from the immediate Calumet area and another third came from Hancock/Houghton. The remaining third of visitors came from elsewhere in Houghton or Keweenaw Counties (15\%), somewhere else in the Upper Peninsula of Michigan (4\%) or out of state (5\%). About one quarter (25\%) of participants indicated that they "almost always" come to First Fridays. Another quarter $(27 \%)$ had come for the first time.

\subsection{Community Capitals and the Arts}

We find that arts-based development relates to each of the seven community capitals. Each capital (or asset type) shapes the circumstances within which arts projects are developed and operate. These characteristics make Calumet both similar to and distinct from other shrunken cities and so have important implications for the generalizability of the findings presented here. At the same time, the various art initiatives contribute to each of the community capitals, sometimes in complex ways. This section both summarizes community characteristics in Calumet and describes how arts-based development is impacting the broader community following the Community Capitals Framework.

Table 1 (on the next page) provides a general overview of the community capitals in Calumet compared to the state of Michigan and the United States. There are no clearly established criteria or specific measures for any of the community capitals. The measures included here were chosen based on data availability and aim to capture a reasonable representation of the various dimensions of each capital. We refer back to the data reported in this table throughout when discussing each of the community capitals in more detail below.

\subsubsection{Natural Capital}

Historically, copper has defined Calumet and the surrounding area, providing the raw material for the community's initial boom and an environmental and cultural legacy that continues to shape and define the region. The broader Calumet area is the site of the most extensive known deposits of native copper (relatively pure copper known as "float copper") that requires little to no processing. Mining of the copper began prehistorically with aboriginal mining to produce jewelry and tools which were traded [39]. Large scale commercial mining operations began in the mid-nineteenth century and continued until 1968 [35]. Altogether, Keweenaw copper was mined for thousands of years beginning about 8000 years ago [39]. 
Table 1. Indicators of the seven community capitals.

\begin{tabular}{|c|c|c|c|}
\hline & Calumet & Michigan & US \\
\hline \multicolumn{4}{|l|}{ Natural Capital } \\
\hline Forested land ${ }^{1}$ & $70.8 \%$ & $52.3 \%$ & $29.7 \%$ \\
\hline Undeveloped area $^{1}$ & $97.1 \%$ & $90.6 \%$ & $94.6 \%$ \\
\hline Trail miles/capita ${ }^{2}$ & 8.17 & 1.36 & $\mathrm{n} / \mathrm{a}$ \\
\hline \multicolumn{4}{|l|}{ Cultural Capital } \\
\hline$\%$ employed in art \& rec & $2.5 \%$ & $1.9 \%$ & $2.1 \%$ \\
\hline Historic properties / capita ${ }^{3}$ & 1.23 & 0.19 & 0.30 \\
\hline$\%$ ID first as "US/American" 4 & $2.8 \%$ & $6.5 \%$ & $9.2 \%$ \\
\hline \multicolumn{4}{|l|}{ Human Capital } \\
\hline Dependency Ratio' & 0.7448 & 0.5998 & 0.589 \\
\hline In labor force & $58.3 \%$ & $61.8 \%$ & $64.3 \%$ \\
\hline Unemployment & $10.8 \%$ & $12.7 \%$ & $9.7 \%$ \\
\hline College Degree & $19.1 \%$ & $25.9 \%$ & $28.8 \%$ \\
\hline Single female HH head' & $6.4 \%$ & $7.3 \%$ & $7.2 \%$ \\
\hline \multicolumn{4}{|l|}{ Social Capital } \\
\hline Violent crime rate * & 1.2 & 4.7 & 4.0 \\
\hline Property crime rate ${ }^{*}$ & 15.5 & 25.9 & 29.0 \\
\hline Religious adherents ** & $42.9 \%$ & $42.1 \%$ & $48.8 \%$ \\
\hline \multicolumn{4}{|l|}{ Political Capital } \\
\hline Voter turnout 2012 & $59.5 \%$ & $63.5 \%$ & $58.2 \%$ \\
\hline \multicolumn{4}{|l|}{ Financial Capital } \\
\hline Poverty & $21.4 \%$ & $16.8 \%$ & $15.4 \%$ \\
\hline Median HH income & $\$ 32,073$ & $\$ 48,411$ & $\$ 53,046$ \\
\hline Median housing value & $\$ 60,800$ & $\$ 121,700$ & $\$ 176,700$ \\
\hline \multicolumn{4}{|l|}{ Built Capital } \\
\hline Pre-1940 housing & $72.9 \%$ & $15.4 \%$ & $13.5 \%$ \\
\hline Vacant housing' & $24.3 \%$ & $14.6 \%$ & $11.4 \%$ \\
\hline GRAPI > 30 & $59.7 \%$ & $54.8 \%$ & $52.3 \%$ \\
\hline
\end{tabular}

${ }^{1}$ Data for Michigan and US total from USDA, Economic Research Service calculations from 2007 based on reports and records of the US Department of Commerce/Census Bureau and Federal and State land management and conservation agencies [40]. Data for Calumet are based on data for a seven county region across the western Upper Peninsula of Michigan and data processed and aggregated by the authors from the National Land Cover Database 2011 [34]; ${ }^{2}$ Trail data for Calumet are collected from local organizations. Data for Michigan are reported by the state at www.michigan.org/trails. Neither estimate is complete but both capture the major trails in geographies. Both are divided by population reported at Census 2010. Results are reported per 1000 residents; ${ }^{3}$ Data from the National Register of Historic Properties (2015), divided by population from Census 2010. Reported per 1000 residents. In the immediate Calumet vicinity, there are 8 properties or districts listed. Other Data Sources: US Census 2000 SF3 marked with ${ }^{4}$; US Census 2010 marked with '; 2010 Religious Congregations and Membership Study marked with **; Uniform Crime Report (2009-2013 five-year average) marked with *; Voter turnout data from 2012 general election; otherwise source is American Community Survey 2009-2013 [41]. Dependency Ratio = (population under 18 and over 65)/population age 18-64. GRAPI is Gross Rent as Percentage of Income as calculated by US Census Bureau. Single female headed households only include those living with own children under age 18. NOTE: Data on religious adherents are only available at county level and shown here for the entirety of Houghton County. Crime data shown for Calumet include crimes reported in Village of Calumet and Village of Laurium.

The lingering importance of copper is indicated by the extensive use of the word copper in names for festivals and descriptions of the area (i.e., "CopperDog 150" dogsled race and "Copper Country" or "Copper Island" as a name for the region). The legacy of copper mining also persists in the miles of underground mining tunnels (now flooded), the thirty-seven mine shafts (now capped), slag piles of poor-rock that tower over the landscape, and a Superfund site in a neighboring community where copper mined in Calumet was processed. There is no acid-mine drainage in this area (the rock did not contain sulfides), so compared to other former mining regions, there is relatively little damage to water quality. However, the Torch Lake Superfund site (where the ore was processed) shows evidence of toxic PCBs, mercury, arsenic, and copper in the water and associated fish toxicity [42]. 
At the same time, Calumet is rich in other natural resources (i.e., timber, fresh water) and outdoor recreation opportunities (see Table 1). The land is heavily forested and access to Lake Superior and its miles of public beaches is about five miles away. The township maintains a public park at the nearest access point that offers sandy beaches, playground equipment, gathering and picnic space, shelters, and basketball courts. The community is centrally located on the Keweenaw Peninsula with easy access to hundreds of miles worth of non-motorized summer and winter recreational trails for hiking, mountain biking, kayaking, snowshoeing, cross country skiing and snow biking. There are seven extensive public non-motorized trail systems within 50 miles of Calumet, each of which includes dozens of miles of maintained trail; and dozens of smaller trails less than ten miles in length.

Within Calumet township, there are at least 53 miles of publically accessible maintained trails, or about 8.2 miles worth for every 1000 residents. Most of these miles are in the Swedetown Recreational Area which includes $30 \mathrm{~km}$ (18 miles) of groomed cross-country ski trails plus $10 \mathrm{~km}$ (6 miles) of designated snowshoe trails for winter recreation. It also includes 25 miles of singletrack mountain bike trails, plus an additional 20 miles of two-track trails for hiking, biking, and running in the summer months. Snowmobile/ORV trails are also plentiful.

The region is internationally known for its cross-country ski trails and good conditions and regularly hosts national cross country ski competitions. It is also internationally recognized as a mountain biking destination, with the bike trails at Copper Harbor (a half-hour drive from Calumet) one of eighteen communities around the world designated as an International Mountain Biking Association silver level (or better) Ride Center (www.imba.com/model-trails/ride-centers).

With regards to arts development, we find evidence of art encouraging natural capital value shifts away from extractive focus toward aesthetics and recognizing socioecological connections. Whereas mining encourages an extractive-based relationship between society and the natural world, the arts-based development draws on the natural environment to inspire creativity and connections to the landscape. The artwork itself communicates these messages to its audiences. The artists we interviewed emphasized the importance of "nature" as a subject matter and source of inspiration. In talking about the kind of work they do, they told us things like "I find that I sorta gravitate to the lake and paint nature", and "I'm a photographer, so subject matter is here...nature ... I'll do a lot of nature photography ... waterfalls, local scenes".

Our team observed that natural capital is the major influence on the art produced in the area. Virtually all the art displayed was of an outdoor theme either depicting wildlife or nature. The artwork tends to focus on appreciating aesthetic and scenic values of the natural world as well as recognizing human connections to ecosystems. Another common theme critiques the environmental impacts of the legacy of mining in the region through images of industrial ruin. Still, more work uses local natural materials, especially copper, beach rocks, birch, and bird's eye maple for crafting jewelry, sculpture, furniture, and frames. Altogether, the themes present in the art subtly encourage a value shift toward appreciating the natural world more for its spiritual, aesthetic, and connected ecosystem values rather than seeing it as resources to be used for human gain.

One risk to natural capital associated with the arts, in general, is that it can promote viewscape fetishism [43] whereby people seek out, pay for, and develop the most scenic natural areas. These practices are relatively common among second homeowners and natural amenity-based migrants and retirees [44]. As Kondo Rivera and Rullman [45] (p. 174) find, fetishizing scenic views "protects the idyll but not the environment" as people develop sensitive natural areas for human housing and recreation. Literally, framing such scenes through artwork and showing it to audiences as desirable may only further these practices. In the Calumet case, we did not collect evidence that would indicate whether or not art development or associated viewscape fetishism are having a physical impact on ecosystems. 


\subsubsection{Cultural Capital}

Calumet's cultural heritage is shaped by a large number of ethnic immigrants who came to the community in the late nineteenth and early twentieth centuries (especially Finnish-Americans) and the shared legacy of the copper mining industry. At Census 2000, 47\% of Calumet residents identified their first or second ancestry as Finnish, compared to only $0.3 \%$ of people across the US. The second most common ancestry in Calumet is German (10\%), followed by Italian ( $8 \%$ ) and French $(7 \%)$. Only $2 \%$ of the Calumet population identified their first ancestry as US or "American", compared to $9 \%$ of people across the country who did so (see Table 1). Architecture and names of commercial blocks and church buildings reflect the multiple faiths and nationalities associated with this diverse ethnic population.

The bitter labor strike of 1913 and the tragedy at the Italian Hall changed the cultural fabric of the community [46-48]. As has been the case in other post-industrial towns, the slow and steady decline in mining employment, population (human capital), infrastructure (built capital) and financial capital which continued for at least seventy years left Calumet with a legacy of dependence on external forces for its identity and a perception that the community has limited power to shape its destiny $[4,35]$. Still, our research team observed and learned through interviews that the community retains an intense sense of pride and "sisu"-generally translated from Finnish to the general idea that the people are survivors.

Two especially strong sources of cultural capital are the historic buildings and associated mining heritage that are well documented, preserved, and interpreted through the Keweenaw National Historical Park (KNHP), which is headquartered in Calumet, and by other organizations. There are eight buildings or districts (neighborhoods) in Calumet on the National Register of Historic Properties. These properties are supported, in part, by the KNHP, which was established by act of Congress in 1992 after more than twenty years of community-based efforts to raise awareness of the national significance of the copper mining industry in the Keweenaw. The Park operates in cooperation with twenty-one heritage sites that are owned and operated by state and local governments, private businesses and nonprofit organizations. The Park's Visitor Center and five of these heritage sites are located in Calumet and interpret the community's heritage.

Our analysis shows that Calumet's art scene fosters a sense of community, community identity, agency, and diversity of ideas among people who visit art spaces. In response to an open-ended question posed to art space visitors, $26 \%$ of survey respondents mentioned that First Fridays allows them to "be a part of something" and that it fosters a sense of community. Participants shared that they engage with First Fridays and the art scene because they want to be involved in something community-minded and to support the artist community and the small businesses.

The art district fosters community identity by celebrating the community's mining legacy and ethnic heritage, but also by introducing alternative sources of community identity as an "arts district" and as a place with abundant natural resources, scenic beauty, and outdoor recreation opportunities. It is common to hear conversations in the galleries where elders and long-term residents pass on some of the history of place, such as prior use of specific buildings or how crowded the downtown used to be. Much of the art itself is based on local community identities. The mural shown in Figure 5, for example, celebrates the cultural legacy of the Calumet community. This piece was commissioned by the Calumet Township Supervisor and it is hung in the lobby of the township office building, making it accessible to a broad audience beyond people who typically frequent art galleries. The local topics encourage audiences to consider the uniqueness, opportunities, and challenges associated with this community. Altogether, the arts district fosters the identity that while Calumet has certainly been shaped by its mining past, it is not "just an old mining town", but that the community is also something more, that is has a future. Our team observed this line of thinking not just among arts enthusiasts, but among a variety of community residents and leaders. 


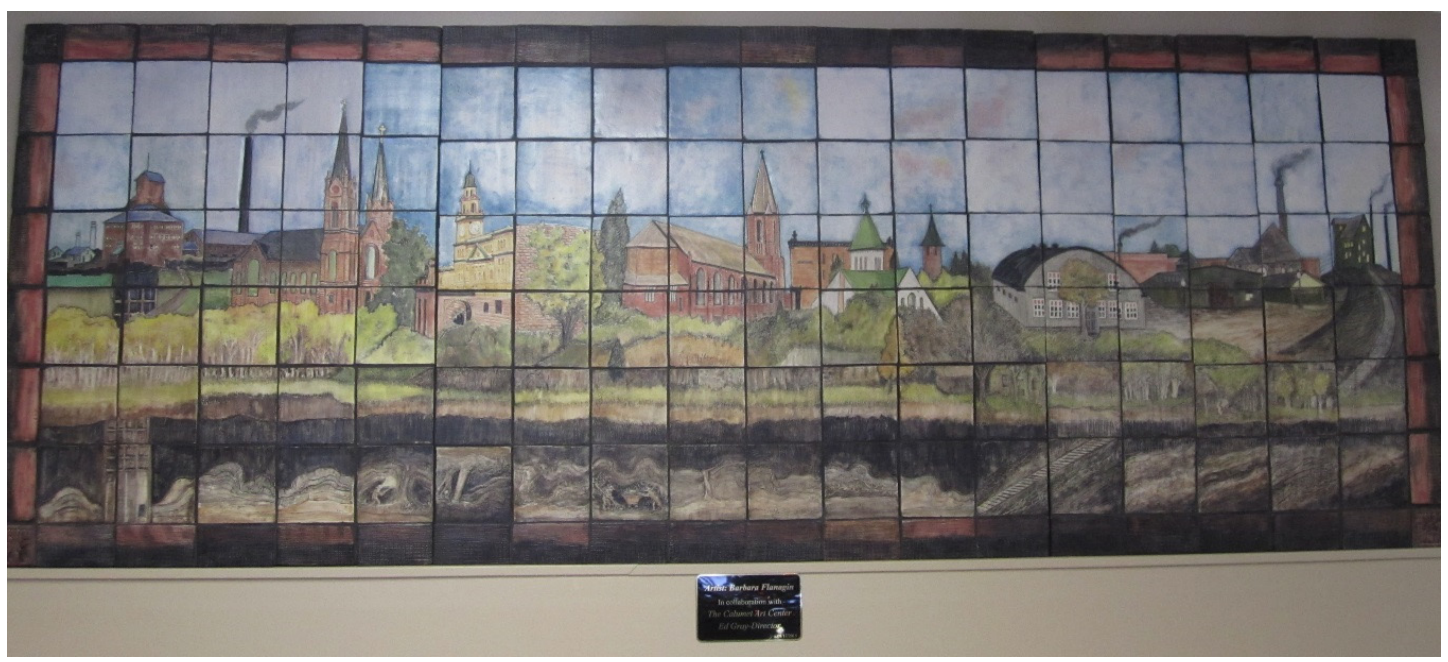

Figure 5. "Calumet Skyline, Over \& Under, Now and Then". Mural made of clay tiles by Barbara Flanagin, under the mentorship of expert potter Ed Gray of the Calumet Art Center. Mural hangs in the Calumet Township office building.

The arts also foster a positive sense of agency, demonstrating that the local community can take control of its own destiny to create positive change. The very existence of the multiple art spaces which have opened in Calumet in the last fifteen years are evidence of the ability to make change. Art space visitors valued First Fridays because they were "uplifting" and "inspiring" and because they provided a "positive energy" and a "vibrant" atmosphere. Others commonly mentioned that they valued the art scene for the exposure to new ideas they got from looking at the art and engaging with others. On the other hand, our team did observe tension in the community between older visions of the community identity (strongly connected to mining and hopeful that mining would someday return) and those with alternative future visions (looking to the arts and outdoor recreation as the community's future identity).

\subsubsection{Human Capital}

Outmigration from the Calumet area and limited employment opportunities have resulted in a relatively small working age population as shown by the dependency ratio (ratio of dependent population under age 18 or over age 65 to the working age population 18-64). This means that there are relatively few people in more economically productive ages to care for the relatively large number of dependents. Due in part to the large number of people over age 65 , only about $58 \%$ of the population age 16 and over are in the labor force. Only $19 \%$ of adults age 25 and over have a college degree, compared to $26 \%$ statewide and $29 \%$ nationwide. One of the goals of Calumet's arts-based development is to attract and maintain more of the younger/working age and college-educated population. Research shows that more highly educated people tend to be more likely to be interested in and attracted to the arts and to places with lively art scenes [20,49].

Since the development of the arts scene in downtown Calumet, the longtime population loss in the downtown core has stabilized. Population in the downtown village declined by over $18 \%$ in the 1980s (average loss of about 18 people per year) and by over 10\% in the 1990s (average loss of 8.5 people per year), but only by $2.5 \%$ in the 2000 s when the art district was developed (US Census Bureau, 1980, 1990, 2000, and 2010 [38]). This correlation does not necessarily mean that arts development was the most important factor in stemming population loss- there certainly could have been other contributing factors and the speed of decline had slowed even in the 1990s before the arts development was underway. It could simply be that those who had the means or inclination to leave had already done so before 2000. Still, the interviews and surveys we reviewed suggest that the 
arts district is one factor that is attracting some people to the community and keeping some existing residents in place. The combination of affordable housing and a vibrant art community makes Calumet an attractive location for artists and a place where some can make a living doing art. As a one artist we interviewed explained:

"I hope that I can always make work that challenges me and that I can make a living doing it that way. That's part of why I moved here, I guess, because the cost of living here is much less for me and I don't have to compromise necessarily what I want to make."

The art district provides at least partial employment and/or supplemental income to a growing number of artists and entrepreneurs. One painter we interviewed explained that before First Fridays started and the art scene in Calumet really started to coalesce, he only sold one or two paintings a year, but now he has sold out a number of shows and he has a regular source of income through art. A ceramic artist described her ability to make a living from art in Calumet as challenging but doable given the general affordability of living in the community. She says:

"I have a line of functional work that tends to be more saleable and that brings in more money and I also make some sculpture and do some painting that is more my kind of personal work. The majority of my work, when I sell it, tends to be kind of 'events'. I'll ... have a big opening and usually the show will then, you know, kind of sell out, and that has happened up here in Calumet in a couple of the different shops. You know everything is relative, so you know making a thousand dollars on a Friday night in this venue, is very different than where I moved from. You know, it's like a month's worth of wages (laugh)."

The arts also provide an opportunity to be productive for several of the senior residents of the Calumet community. For example, the Copper Country Associated Artists cooperative includes about 30 members who are over the age of 62 (75\% of total membership). The team learned through interviews that several of these seniors rely on art sales for supplemental income. Given the high dependency ratio in the community, having this opportunity to remain economically productive in later years could potentially reduce some strain.

Dozens of artists show and sell their work in Calumet's art spaces each year. Interviews with gallery managers revealed that approximately 45 artists participate in the Copper Country Associated Artists cooperative, about 75 different artists show work at the Paige Wiard Gallery each year, about 10-15 artists exhibit each year at Galerie Boheme and another 15 exhibit at the Calumet Art Center. Yet, most artists in Calumet do not rely on art as their main income, and those who do create utilitarian or functional art that is more likely to sell in addition to art that is more of a critique or process piece. The professional artists we spoke with noted that they are only able to make a moderately viable income selling art that is not consistent or secure. Many also teach art and/or have other jobs to supplement their income. Because of a weak local economy, Calumet must rely on summer tourism and occasional events that attract people from extended communities to sell art.

There is also some potential for job creation in building restoration and revitalization efforts that are inspired by demand for art spaces. There are several examples our research team heard about in the course of this study. Galerie Boheme is located in a building that was vacant and in need of repair before the current owner purchased it and restored it as an art gallery and workspace with living quarters upstairs. Similarly, the remodeling of the Omphale Gallery was the vision of one artist who hired local contractors and carpenters to remodel the first floor space into a gallery and café. A local photographer recently purchased a building on Fifth Street and is using local contractors for the electrical work. A local developer who recently rehabilitated the former Morrison School into apartments rents prime space to an artist for gallery/studio space.

The arts district also builds and rewards skills in making. As one artist we interviewed described, "I think there is a whole movement to buy local, to buy handmade. People want a different experience, not something that is mass produced, and I'm totally behind that." She was referring to the fact 
that artists can hand-make items that are in demand, and arts districts provide opportunities for people to develop those skills and talents. The Calumet Arts Center is built around this philosophy. They opened in 2008 in an old church building and focus on offering art classes in claywork, painting, print, weaving, and glass beads primarily to children, but also to adults. Approximately 60 middle and high school students participate each week in art classes as well as 75-100 adults who take classes each year through the center. Each year, 8-12 different artists instruct classes through the center and about 15 different artists exhibit there. They also offer a mentoring program that partners emerging artists or artists who want to learn new skills with established and expert artisans. The center reaches out to low-income, veterans, and tribal community members through partnerships with the Keweenaw Bay Indian Community. Copper Country Associated Artists also seeks to build skills offering hands-on arts experiences each month during First Fridays free of charge to the public and attracting between 20 and 75 participants each month.

\subsubsection{Social Capital}

"Social capital refers to features of social organization, such as networks, norms, and trust, that facilitate coordination and cooperation for mutual benefit" [50] (p. 35). Social capital is one of Calumet's strengths and residents are proud of the work they accomplish by coming together to support various initiatives. Violent and property crime rates are low (a quarter to a half of the state and national averages, as shown in Table 1). Volunteering and collaboration norms are strong, and community social organizations are prevalent and active.

There are multiple organizations, clubs and volunteer groups that do community or charitable work. For example, Main Street Calumet, a grassroots organization aimed at revitalizing the downtown district, partners with the village administration, the Downtown Development Authority (DDA), the Keweenaw National Historical Park and Calumet Township to help organize community improvement projects. Main Street has about 10-15 core volunteers who put in hundreds of hours each year plus another approximately 50 volunteers who help with special events. The Swedetown Trails Club, a volunteer organization with over 400 members, helps maintain and pay for grooming cross country ski trails near downtown Calumet. The Calumet Lion's Club recently raised \$15,000 and donated hundreds of volunteer hours to help Calumet Township develop a barrier free walking path, disc golf and picnic area at Calumet Lake. The Copper Country Curling Club raised $\$ 32,000$ in matching funds to make improvements to the former mining company shop which they use for indoor curling. The Copperdog 150 dogsled race event uses about 600 volunteers annually to support a dogsled race that attracts thousands of spectators to Calumet. The Calumet Hockey Association member/players pay for ice time and the operation of the ice rink at the Calumet Colosseum. The Rotary, Calumet Lodge 404 Elks, and other groups raise money for local scholarships and other charitable work. These are just a few examples (not exhaustive) of the organizations that help provide recreational, cultural, and professional opportunities that attract visitors and residents to the area that the village and the township would not otherwise be able to afford.

Collective organizations associated with the arts include the Copper Country Associated Artists cooperative (CCAA), the Calumet Art Center, and the Calumet Arts District. CCAA is a 45-member organization that maintains gallery space, puts on public demonstrations or activities each month, provides a social network for its members, and promotes the arts. The cooperative is a non-profit organization funded by member dues, gallery commissions on member art sales, and from vendor fees (fees for service) from its annual juried art show. Decisions are made democratically- some are made by an elected board that meets monthly, but most decisions are made collectively by member vote. The main purpose of the CCAA is to "support artists and the community". The Calumet Art Center is a non-profit $501 \mathrm{C} 3$ with a primary focus on arts education (especially traditional arts, culture and history) and reaching out to diverse publics to promote involvement in the arts. It is funded primarily through memberships, grants, and donations, but also from fees for service (art classes, performance hall fees) and art sales. The art center is managed by an Executive Director who oversees 
daily activities with a limited staff and volunteers, and reports to a board of directors who oversee the operation. The Calumet Arts District is a newer and loosely formed group that organized with the aim of coordinating efforts across the various art spaces in Calumet and promoting Calumet as an arts community. It does not have a budget, and decisions are made collectively using a consensus model.

It is important to consider the impact of the arts on both bonding and bridging social capital. Bonding describes connections among close-knit individuals and groups who typically share a common background. Scholarship suggests that such bonds among residents empower them to protect and pursue their collective interests [50-54]. Yet, bonding social capital can exclude individuals or groups and divide communities along economic, race, age, or other cultural lines $[55,56]$. In order to promote inclusive networks, bonding social capital must be balanced with bridging social capital $[15,16,51,52,57]$. Bridging social capital connects diverse and different groups within the community to each other and to other groups outside the community [51]. Bridging occurs when members of one group connect with members of another group to access support or gain information [52].

Calumet's art activities serve as a catalyst for both bonding and bridging social capital and the various art spaces serve as "third places" (social gathering places outside of home and work) where people can connect [58]. First Fridays facilitate bonding by bringing similar groups of people together in a common space to socialize. A very consistent theme among the people we spoke with was that First Fridays are as much of a social event as an art event. This was an important point that people wanted to emphasize. One artist we interviewed explained that First Fridays are "something to do, hopefully its somewhere you'll see people, kind of celebrate what's going on". Another Calumet resident spoke of First Fridays saying: "It's a vibrant event and gives area artists a chance to connect with the public. Everyone I know really appreciates this monthly opportunity. It also gives a 'meeting place' venue for art aficionados and folks coming for the first time to gather and share comments and meet the artists and new people". This illustrates the importance of the space for building this kind of bonding social capital, bringing together people with similar interests on a regular occasion.

Most of the First Friday's visitors (73\%) surveyed had previously attended the event. They often knew each other, the art space owners/managers and the artists who exhibited there. This created an overall atmosphere of familiarity, but one that could be exclusive to people who are not already insiders. For instance, one member of the research team observed that "once inside [the gallery] it became very apparent that everyone knew each other and you felt like you were interrupting something". This is one example of how the Calumet arts district forms boundaries that can serve as a deterrent for new individuals to feel comfortable. Several observations indicated that there was a real or perceived boundary between the visitors to First Fridays and the wider Calumet community. Another participant observed that "the artists are a little bit uppity and people who aren't artists feel excluded from the First Friday experience". This boundary was partially formed as a result of the somewhat narrow appeal of art to the wider community and also the observation that many people already knew each other at the First Fridays events. Another First Friday regular remarked that they are "sort of stagnant" with the same people attending all the time and needing "some new life to them". Several observations remarked on the lack of young people frequenting the art district $-75 \%$ of visitors we surveyed were over the age of 50. Still, all of the observers in the research team (most of whom were young adults in their 20s) articulated a consistently positive social atmosphere and a sense of feeling welcome at all of the art spaces.

Despite the somewhat insular nature of the bonded social capital observed, First Fridays also created positive bridging social capital. First Fridays helped draw different groups of people to Calumet. Survey data indicated that $27 \%$ of visitors to First Fridays were visiting for the first time and that the majority of visitors were actually from outside of the immediate Calumet area, with the majority being from the Houghton/Hancock area (37\%). Moreover, many of the artists in Calumet have lived elsewhere around the country at some point in their lives and maintain connections with distant art organizations and widespread social networks. Tourists are also attracted to the art scene and draw new types of people with different networks into the community. In these ways, the emerging art 
district in Calumet appears to be bridging different groups, organizations, and individuals together through weak, but important networks [59].

Altogether, the data suggest that Calumet's art district is strengthening close ties among people engaged in the arts and who regularly attend First Fridays and visit the galleries. It is bringing together similar people to socialize on a regular basis and help them to identify common interests and to share community interests. It is also helping to establish some weaker networks (bridging) between residents of the broader region, tourists, newcomers, seasonal residents, and art-related organizations and actors from across the country and around the world. However, the same bonded relationships present a challenge for First Fridays in that they can lead some (new people or different people) to feel excluded from the art scene. The art scene does not appear to be adequately bridging social capital between different social groups within the local community. From our observations there appears to still be the folks who engage with First Fridays and the folks who do not, with younger people and lower income people mostly left out of the art scene (with some exceptions, especially those promoted by the Calumet Art Center).

\subsubsection{Political Capital}

Political capital is about the inclusion of different voices in the community and the ability to get things done, make decisions locally, and enforce codes. Calumet, like many post-industrial towns, was left with a legacy of dependence on external forces (e.g., C \& H Mining Company, Jasper, AL, USA) and the perception that the community has limited political power to shape its own destiny. The community continues to suffer from a certain degree of acquiescence to the status quo [4]. The Calumet Township Board of Trustees have all served for several years, all identify with the same political party, and have run unopposed for the past several elections. The same Township Supervisor (elected position) has served the community for 43 years. There is little diversity of voice in the governance of this community and there are relatively few residents who are willing to run for office. This is particularly true in the downtown core area, which is administered as the Village of Calumet. Those who are willing to get involved sit on multiple committees and boards.

Voter turnout in the broader Calumet area is similar to the US national average (about $59 \%$ in the 2012 presidential election), but within the downtown Calumet core area (Village), turnout is lower at 44\% [60]. The Village of Calumet Civic and Commercial Historic District and Ordinance was established in 2002. The Village recently made changes to its historic district ordinance to address "demolition by neglect" but does not have a minimum maintenance standard and struggles to enforce its ordinances. The administration does not have the financial ability to hire someone to enforce a minimum maintenance standard or to bring violators into compliance.

Still, some people with different or new ideas have been able to get traction and make change in the community often working behind the scenes or not directly through formal leadership structures. One example is in the establishment of the Keweenaw National Historical Park (KNHP). After the mines closed in 1968, many of the historic mining buildings were repurposed or lost to abandonment, fires or the wrecking ball. One of the most poignant losses occurred in 1984 when the Calumet Village Council voted to demolish the Italian Hall, the site of the Christmas Eve tragedy in 1913. The building had fallen into disrepair after years of neglect. A group of concerned citizens made an effort to stop the demolition, but failed to raise enough funds to save the building. The demolition of the Italian Hall was a catalyst for a renewed effort to save what remained of the community's architectural and mining legacy. A grass-roots group formed in 1987, to lead an effort to establish a national park in Calumet. After years of community driven effort, the Keweenaw National Historical Park was established on 27 October 1992 [61].

The development of the arts district itself resulted from an artist in the community who saw the vacant downtown and buildings in disrepair and felt that something must be done to revitalize the community. He saw an opportunity for the arts and worked through his own private funds, personal initiatives, and social networking to start opening galleries and other art spaces. 
Today, the art scene challenges the current political structure in Calumet in three ways. First, art is a medium through which people (even relatively powerless people such as low income children taking art classes at the Calumet Art Center) can find, express, and communicate their own voice. Sometimes the art created makes a political critique and can be an avenue through which people can raise their concerns and/or challenge existing systems. Teaching people to find this voice through arts education (e.g., at the Calumet Arts Center and the CCAA) and exhibiting work from a variety of artists in galleries across the community are ways that the arts district is opening up space for multiple voices that may not otherwise have any public hearing. Several artists we interviewed remarked on how unique the art scene in Calumet is because it is not hard to get shows or exhibit space. You do not have to be a highly established artist to get your work seen in public. This fact opens the door to less powerful groups to share their ideas through art, and it may be a common characteristics in shrunken cities.

Second, First Fridays allows artists and those who regularly attend and engage with the art scene to gain some political capital as a group they may not otherwise have as individuals. The monthly nature of First Fridays has provided a regular social venue which allows for the exchange of ideas and social connections among artists, art space owners, and tourists. One initiative that has come out of the regular interaction at First Fridays has been an effort to improve the downtown windowscapes in both occupied and vacant buildings. Our team observed that a regular topic of discussion at First Fridays events is on the state of disrepair or blight in the downtown. In light of these discussions, two artists decided that one way they could make a difference would be to stage windowscapes across the communities with a "windows into the past" effort. Many downtown buildings were full of storage or trash or boarded up. The artists brought their idea to the KNHP and partnered with the local school and businesses to research past uses of downtown buildings, make posters explaining their history, and then decorate windows to show the posters and antiques to create an image of the past. The effort has been successful and, as one of the artists who worked on the project explained, "it is definitely something that has changed the atmosphere downtown. Everybody comments on that. Some of those buildings that have been vacant and for sale for years, sold after we did that. I think it might have made a difference".

Finally, the development of multiple galleries and art spaces throughout the downtown area has created a new power base with different interests and led by a different group of people in comparison to the more traditional and long-time community leaders in this community, many of whom still have ties to the mines and related businesses that were prominent in the community in the early twentieth century. These leaders are not directly or officially incorporated into governance structures, but they do constitute a political voice that requires some attention. In Calumet, the development of the arts district was homegrown and small scale. It is locally controlled and demonstrates a shift away from relying on external corporatism to community residents with relatively few resources shaping their own futures. The result is the beginning of a more pluralist set of interests and voices in community leadership and a growing sense of agency and independence in the community.

Despite these opportunities, coordination among the various arts-related groups is not well developed and collaboration between galleries has been challenging without a clear leadership or organizational structure. To begin to address these issues, the Calumet Arts District was formed in 2013 to promote the visual arts, bring the various galleries and art spaces together in order to better promote the district as a whole, share costs for advertising, create a more organized effort for First Fridays and discuss issues related to the downtown and the art scene in Calumet. Since 2013, the group has created a rack card and map listing all of the art spaces, collaborated on group advertising, and created lively yellow flags which identify the art spaces during events like First Fridays. The group is currently working towards a more organized structure, and is refining its definition of art gallery/art space and developing an annual advertising budget.

While the arts make space for political critique and organizing for change, political action for community change or leadership among artists and art enthusiasts, outside of clearly arts-related 
activities, has been minimal or nonexistent. In addition, despite the grassroots agency involved in developing the arts district, its success remains dependent upon outside forces, now in the form of tourists, visitors from nearby communities, and seasonal residents.

\subsubsection{Built Capital}

One of Calumet's most defining characteristics is its rich architectural heritage in the historic downtown area, which is designated a National Historic District. Most of the built infrastructure dates to the early-twentieth century when Calumet was a vibrant and growing city with tens of thousands of people in the local area and a great deal of wealth. The infrastructure was built to serve a city of 50,000-100,000 residents [35]. Many of the downtown buildings are comprised of a beautiful and highly sought after reddish-colored Jacobsville Sandstone, quarried in the region. Calumet also has distinctive historic homes built by mining executives, the Calumet Theatre, and numerous other historic structures. Most of the housing stock (73\%) was built before 1940 (see Table 1).

Historic buildings pose both challenges and opportunities. Architectural heritage encourages tourism and political efforts to help preserve the unique historical legacy. The buildings connect the community to its past and offer a sense of identity and uniqueness. Yet, many of these historic structures are uninhabited and in danger of collapse due to a combination of deferred maintenance, extreme winter temperatures and heavy snow, and expensive heating costs. The loss of buildings to abandonment and neglect decreases the tax base and the municipality's ability to provide services.

Property values are low and a large proportion $(24 \%)$ of homes are vacant. According to the American Community Survey (2009-2013), 84\% of owner occupied housing units in the downtown Village are valued at less than $\$ 100,000$. Low property values further limit municipal ability to generate tax revenue. On one hand, the community does not want to part with their properties. On the other hand, they do not have sufficient economic and financial resources to maintain them. The result is a vicious cycle where historic buildings are valued, but not preserved because of lack of funds.

Artists have been instrumental in restoring and preserving some of Calumet's historic buildings, stabilizing and restoring them to serve as commercial or non-profit art spaces. Most of the current art spaces are located in historic buildings that were in need of rehabilitation. The buildings are more than simple infrastructure: they are part of the art itself. For instance, the Calumet Art Center is located in a historic church. Because the buildings that artists have restored are clustered in the downtown core near one another, the collection of restored historic buildings serves as a valuable community legacy that contributes to community identity. The buildings are witnesses of the past and communicate the community's heritage to residents and visitors.

At the same time, arts-based development of low-value, yet historically desirable buildings raises concerns for the potential of gentrification to price low-income residents out of the housing market. Despite very low property values (see Table 1), housing affordability remains a struggle in Calumet because of low incomes and lack of updated, safe, accessible housing. Housing cost burden is high with an estimated $60 \%$ of renters spending $30 \%$ or more of their income on housing costs in the broader Calumet area (63\% in the downtown Village), in comparison to $52 \%$ of renters who spend this much nationwide [41]. Affordable, quality housing is in high demand; but in the data we collected, we found no indication of arts-based gentrification pricing people out. The impact of the art district has simply not raised values, given the large number of vacant properties and old buildings that are available in this city that was built for a population ten times its current size. If anything, the arts district has increased the amount of affordable housing available in the downtown by providing some incentive for developers to restore buildings with apartments in the upper floors and store fronts in the lower levels, rather than to simply allow these spaces to decay. Our team interviewed two local developers each of whom recently remodeled historic buildings in downtown Calumet for high-quality affordable rental housing. The emerging art scene is one of several factors that make their investment worthwhile.

Beyond historic buildings, built capital encompasses broad sets of infrastructure including roads, utilities, water systems, and other physical structures. As in other shrunken cities, Calumet's 
infrastructures is aging, suffering from poor maintenance, and is overbuilt. We did not uncover any evidence that arts-based development has had any impact on built capital development other than with regards to historical buildings.

\subsubsection{Financial Capital}

Financial sustainability is one of Calumet's biggest challenges both in the public sector as well as for many residents and businesses. An estimated $21 \%$ of Calumet area residents fall below the poverty line (see Table 1). In the downtown core the poverty rate is substantially higher at $48 \%$, compared to the state of Michigan total at $17 \%$. Median household incomes are significantly below state or national figures. Housing values are low (median values are about $50 \%$ of the state median) and this, along with population decline, reduces the tax base for municipal governments. Moreover, because of the small population and low-income, there is little incentive for new businesses or financial institutions to invest in the community.

Calumet's downtown businesses are vital to the local economy. With few exceptions, the downtown cafés, restaurants, galleries, and businesses are unique and locally owned and operated. These businesses bring in dollars from outside the area (tourists) as well as helping keep local dollars in the community encouraging people to buy local. The arts district brings customers into the community and raises awareness about the businesses in Calumet. Several comments from gallery owners and art space visitors in our surveys and interviews indicated that First Fridays are an important community event that brings visitors back into the downtown shops and cafés even if they do not buy anything that very evening, they sometimes come back and purchase later.

In addition, the arts scene has spurred significant public and private investment in Calumet over the past several years, including the opening of several private and non-profit galleries in the downtown. Most of the art spaces are operated with private funds, bring some level of employment into the downtown. These businesses have also brought degraded buildings or buildings that had been tax-forfeited back onto the tax rolls. Several art spaces contribute to the local economy by providing affordable housing (upstairs) for residents, artists and visitors. The Paige Wiard Gallery, Café Rosetta, Cross Country Sports, Galerie Boheme, Artis Books, and a new photography gallery all have apartments on the upper floors which provide housing.

Based on our team's observations, the informal economy does appear to be active in Calumet. This seems to revolve around paying cash for goods or services such as childcare, construction work, or firewood. There is also some level of trading, and one artist mentioned in an interview that she was able to trade art for vegetables and other needs at times. Because this was not the primary topic of our investigation, we have only limited information about the informal economy.

All told, given the degraded tax base, the overbuilt and aging infrastructure, and the low income and high needs in this community; the financial capital generated from the current arts scene helps but is not enough to meet the challenges.

\subsubsection{Summary of Results}

Altogether, the arts district promotes each of the seven community capitals in key ways, but it also introduces important challenges (see Table 2). Given the particular challenges and opportunities associated with the shrunken city context (especially vacant downtown buildings, affordable rents, degraded tax base, and aging and overbuilt infrastructure); the arts district in Calumet promotes a sustainable future by allowing people to see an alternative, hopeful, and vibrant path forward. The arts have been instrumental in helping give the community an emerging new identity as a unique community that has a future in art, outdoor recreation, and connections to heritage landscapes. This identity challenges competing visions of the community as a "worn-out old mining town" that was built by and remains dependent on mining and that is gradually crumbling away.

This kind of hope and place attachment is critical for Calumet's future. The Village Administrator who said that he sees outdoor recreation and arts as two key paths toward Calumet's future, explained: 
"I can see the potential here. There is some positivity. Therefore, much potential. We got to try to get away from the infighting. People are saddened by the current state of the community and if we can see some positivity, people will come out and support us. They want that ... You can look at our downtown and it's got such cool facades. Property is cheap. We want to bring some vibrancy back to downtown. But you're not going to get a quick flip. The buildings might not be worth anything now, or you might be able to purchase one for a few thousand dollars, but it will take a couple hundred thousand just to get it stable. You're not going to see the economic return in your lifetime. You've got to have people to fall in love with the area and invest. You have to find someone who will do it for the love of the place".

Table 2. Summarizes key findings with regards to how arts-based development impacts aspects of sustainability.

\begin{tabular}{lll}
\hline \multicolumn{1}{c}{ Community Capital } & \multicolumn{1}{c}{ Promotes Sustainability } & \multicolumn{1}{c}{ Challenges Sustainability } \\
\hline Natural Capital & $\begin{array}{l}\text { Promotes value shift to scenic, aesthetic, } \\
\text { ecosystem services, and connection to } \\
\text { landscape; rather than human exploitation } \\
\text { of natural resources }\end{array}$ & $\begin{array}{l}\text { Viewscape } \\
\text { fetishism/commodification }\end{array}$ \\
\hline Cultural Capital & $\begin{array}{l}\text { Promotes place identity, sense of place, } \\
\text { opportunity to celebrate community, } \\
\text { community agency and diversity of ideas }\end{array}$ & $\begin{array}{l}\text { Concern about losing historic } \\
\text { identity; tension between new and } \\
\text { old ideas }\end{array}$ \\
\hline Human Capital & Builds skills, creates jobs & Does not pay enough, few jobs \\
\hline Social Capital & $\begin{array}{l}\text { Provides place/space to connect. } \\
\text { Encourages bonding and bridging capital }\end{array}$ & $\begin{array}{l}\text { Bonding capital can exclude } \\
\text { others, less advantaged groups } \\
\text { often left out }\end{array}$ \\
\hline Political Capital & $\begin{array}{l}\text { Offers space for new/different voices; } \\
\text { opportunity for political critique; easy to } \\
\text { get space (voice heard) in shrunken city } \\
\text { context; more local control; new power base }\end{array}$ & $\begin{array}{l}\text { Little political action (mostly talk); } \\
\text { collaboration can be a challenge; } \\
\text { few resources; remains dependent } \\
\text { on outsider (through tourism) }\end{array}$ \\
\hline Built Capital & $\begin{array}{l}\text { Promotes restoration of historical buildings } \\
\text { and spaces }\end{array}$ & $\begin{array}{l}\text { Risk of gentrification, though no } \\
\text { evidence of gentrification } \\
\text { occurring now }\end{array}$ \\
\hline Financial Capital & $\begin{array}{l}\text { Brings investment (private and public); } \\
\text { attracts customers to downtown businesses }\end{array}$ & $\begin{array}{l}\text { Does not bring enough investment } \\
\text { to support needs }\end{array}$ \\
\hline
\end{tabular}

The arts district, as well as the outdoor recreation opportunities and the uniqueness of place might just provide the type of community identity that will get people (residents, second-homeowners, and even visitors) to fall in love with the community. Several of the artists we interviewed spoke of just this kind of process, when deciding to relocate to Calumet.

Yet, despite its successes, the arts district has not been able to stop the decline in tax base, employ sufficient numbers of people, reduce poverty, or otherwise do much to help the large number of low-income people to get their basic needs met. These are serious critiques. There are also concerns with exclusion of less advantaged groups from close-knit social capital networks and the fact that there has been relatively little political involvement or directed initiatives among the arts groups except for pushing for activities that are clearly related to the arts or to restoring historical buildings or reducing blight. 


\section{Discussion}

\subsection{Calumet and Other Shrunken Cities}

Calumet, like other shrunken cities, faces some unique challenges and opportunities that affect its potential toward a sustainable future. The community's social and cultural capitals are some of its greatest strengths, but critical challenges in human, political, built and financial capital make it difficult for the community to implement innovative project ideas, foster entrepreneurship from within, or even to provide basic services, fund existing infrastructure or conduct basic maintenance. Decades of decline fuel disinvestment, rather than investment, in community initiatives and have led to a spiraling down of community capitals in Calumet. Under these conditions, investing in sustainability initiatives is critically necessary to move this former mining community beyond the bust, but it is difficult and seemingly impracticable to do.

Several of these opportunities and challenges are likely common in other shrunken cities and especially in remote former mining communities. Natural capital in former mining towns has been associated with an extractive process and socioecological relations centered around exploiting the natural resources rather than protection, preservation, or ecosystem services [62]. In former mining and industrial communities, natural capital is often degraded. Threats to human and ecosystem health often remain as relics of the former industry. Human capital suffers as people, and especially those with higher levels of education and resources, vacate the city for jobs and opportunities in other growing and more prosperous locations [20]. Social capital can be challenging to develop without "third places" outside of work and home where people can gather to share interests and build relationships [58]. Such places in the shrunken city may be rare as it becomes less cost effective to offer services to a diminishing number of people.

Politically, shrunken cities may be dominated by more traditional leadership voices who hunker down in a conservative effort to limit change, or they may have reached such a state of turmoil that change becomes accepted as the way forward. Financial struggles are characteristic of shrunken cities, as people and businesses disinvest, property values decline, and the tax base diminishes. Infrastructure is built for a larger base, and with years of decline, maintenance and upgrades are likely to have been deferred creating a situation of overbuilt and aging infrastructure. Culturally, it is difficult to feel prideful and hopeful about a city that has experienced long term decline. For these reasons, shrunken cities might suffer from lack of agency and from negative identity.

Particularly the challenges of overbuilt and aging infrastructure coupled with a degraded and declining tax base can make investing in new programs and even maintaining basic services exceedingly difficult. For example, the Village of Calumet streets department is still using one snow removal machine that dates back to 1946 and others from the 1970s to move snow in an area that receives an annual average of snowfall of over 200 inches a year. The village administrator brought this up in an interview along with the fact that the town hall furnace is over forty years old and in need of replacement. He said, "I don't know what the hell to do. Should I put a closed sign up and go away? That's how scary it is up here. It's really come to that. We can't survive and provide our basic services the way things are now".

Loss of human capital and tax base along with maintaining an infrastructure larger than the current tax base can afford is a problem for many "shrunken" cities [63,64]. However, Calumet faces some unique challenges because of its long winters and extreme snowfall. Energy costs for heating large, older buildings can be cost prohibitive, particularly in this region with some of the highest energy costs in the nation. The heavy snow load takes a toll on buildings that are not maintained or heated. Roofs of abandoned buildings in the downtown are literally collapsing under the weight of snow.

Despite the challenges of the shrunken city, that context also creates opportunities that are helping to make arts development in Calumet a viable sustainable development option. The history as a former mining community and the associated environmental impacts on the landscape offer obvious material 
for artists to critique exploitive socioecological relationships and an opportunity for artworks to start to shift how we value the natural world more towards seeing connections with ecosystems and landscapes. After decades of population decline, the arts are attracting some people to live in Calumet, and they are coming in part because of the affordability of housing associated with the history of decline. Vacant buildings in the downtown and lack of other investment provided the political will to invest in starting galleries and a First Fridays art walk. Sometimes, hitting low points opens minds and provides the incentive necessary to promote change.

Because rent is low, artists and businesspeople are able to economically meet their basic needs without as much pressure to bring in higher incomes that would be necessary in more expensive locations. They are also able to open several art spaces in a small community and to offer plenty of room for multiple artists to show their work. In this shrunken city, it is much easier for artists, even unknown ones, to find opportunities to get their work seen and their voice heard than is the case in more competitive arts districts in growing cities with high rents. While the risk of gentrification should not be ruled out, especially given high poverty rates, affordable rents remain the most promising aspect of the shrunken city context. The abundance of vacant buildings and low value buildings make space available with less risk of gentrification, and the arts provide some incentive for developers to update and build safe affordable housing.

\subsection{Arts as a Sustainable Development Process}

Research on rural community development suggests that social capital, in particular, can stimulate development of the other capitals and create a vital force for a spiraling up process of community investment and change $[16,65]$. The data we collected suggest that Calumet's arts district is building social, political, and cultural capital, and that there is potential for the arts to spur a "spiraling up" process of sustainable community development in Calumet. One of the defining features of the art scene in Calumet is that it is locally grown, small scale, and costs little to nothing to get involved. These factors make art in Calumet relatively accessible and affordable (compared to expensive art museums and juried entries often found elsewhere) and likely increase its positive impact on the local community. However, the impact of the arts on spiraling up is still limited by the somewhat insular nature of its participants. In order to have a broader impact, the arts district would need to increasingly focus on including diverse groups and to provide opportunities for less advantaged people, younger people, parents and children.

The arts are inspiring residents to envision a more vibrant future. Still, the primary impact of arts development has been on social sustainability, with relatively little positive impact on economic sustainability or environmental sustainability. The research described here has focused on social sustainability and sustainable community development, which are better represented in their complexity in the Community Capitals Framework than are economic or environmental sustainability. Environmental and economic sustainability need more attention in future work.

Ultimately, the findings shown here suggest that in the struggling shrunken city context, arts-based development approaches will most likely need to be balanced with alternative strategies that can better meet residents' basic economic needs, which can include a broader range of people who may not be interested in the arts, and that can more directly address environmental issues. Residents in Calumet are aware of these issues and continue to work on multiple sustainable development strategies, beyond the arts. For instance, the community is currently exploring the possibility of tapping into water in abandoned mines to use it for geothermal heating and cooling.

Supplementary Materials: Supplementary Materials can be found at www.mdpi.com/2071-1050/8/3/284/s1.

Acknowledgments: This paper is based on data collected over a three year period by three classes of students and several community members in the Calumet, MI area. The authors wish to thank all of the students who participated in those projects for their contributions to data collection and to helping us understanding aspects of sustainability in Calumet, including: Travis Wakeham, Talva Jacobson, Leopoldo Cuspinera, Rhianna Williams, Ariel Terpstra, Luke Alvin, and Heather Hendrickson. In addition, we would like to recognize the dozens of 
Calumet community members (not named here for confidentiality reasons) who have participated in this project through their conversations and data sharing.

Author Contributions: Lorri Oikarinen collected, analyzed, and interpreted data particularly in the arts section as well as contributed to writing sections of the paper and building networks between the research team and the case community. Richelle Winkler conceived and designed the data collection, managed the multiple researchers who contributed to data collection and analysis, analyzed data and wrote the majority of the paper. Heather Simpson was the student lead in the class that initially collected and analyzed arts data. For this paper, she collected and analyzed interview and survey data, as well as contributed to the organization and writing. Melissa Michaelson and Mayra Sanchez Gonzalez contributed to discussions and understanding of the community capitals in Calumet, collected data, and edited the manuscript.

Conflicts of Interest: One of the authors on this paper (Lorri Oikarinen) is an artist in Calumet and her family owns and operates an outdoor recreation shop in Calumet's downtown. There are no other conflicts of interests among the authors.

\section{References and Notes}

1. England, L.; Brown, R.B. Community and resource extraction in rural America. In Challenges for Rural America in the Twenty-First Century; Brown, D.L., Swanson, L.E, Eds.; Penn State University Press: University Park, PA, USA, 2003; pp. 317-328.

2. Aswathanarayana, U. Mineral Resources Management and the Environment; CRC Press: Boca Raton, FL, USA, 2005.

3. Freundenburg, W.R.; Wilson, L.J. Mining the data: Analyzing the economic implications of mining for nonmetropolitan regions. Sociol. Inq. 2003, 72, 549-575. [CrossRef]

4. Gaventa, J. Power and Powerlessness: Quiescence and Rebellion in an Appalachian Valley; University of Illinois Press: Urbana, IL, USA, 1980.

5. Ross, M.L. The political economy of the resource curse. World Polit. 1999, 51, 297-322. [CrossRef]

6. Nord, M.; Luloff, A.E. Socioeconomic heterogeneity of mining-dependent counties. Rural Sociol. 1993, 58, 492-500. [CrossRef]

7. Humphrey, C.R.; Berardi, G.; Carroll, M.S.; Fairfax, S.; Fortmann, L.; Geisler, C.; Johnson, T.G.; Kusel, J.; Lee, R.G.; Macinko, S.; et al. Theories in the study of natural resource-dependent communities and persistent rural poverty in the United States. In Persistent Poverty in Rural America; Rural Sociological Society Task Force on Persistent Poverty; Westview: Boulder, CO, USA, 1993; pp. 136-172.

8. Freudenburg, W.R. Addictive economies: Extractive industries and vulnerable localities in a changing world economy. Rural Sociol. 1992, 57, 305-332. [CrossRef]

9. Freundenburg, W.R.; Gramling, R. Natural resources and rural poverty: A closer look. Soc. Nat. Resour. 1994, 7, 5-22. [CrossRef]

10. Krannich, R.S.; Luloff, A.E. Problems of resource dependency in U.S. rural communities. Prog. Rural Policy Plan. 1991, 1, 5-18.

11. Peluso, N.L.; Humphrey, C.R.; Fortmann, L.P. The rock, the beach, and the tidal pool: People and poverty in natural resource-dependent areas. Soc. Nat. Resour. 1994, 7, 23-38. [CrossRef]

12. Schwarzweller, H.K.; Logan, J. Ontonagon: A remote corner of Michigan's Upper Peninsula. In Forgotten Places: Uneven Development in Rural America; Falk, T., Ed.; University of Kansas Press: Lawrence, KS, USA, 1993; pp. 168-194.

13. Manteaw, B. From tokenism to social justice: Rethinking the bottom line for sustainable community development. Community Dev. J. 2007, 43, 428-443. [CrossRef]

14. The Johannesburg Declaration on Sustainable Development, 4 September 2002. Available online: http:/ / www.un-documents.net/jburgdec.htm (accessed on 28 January 2016).

15. Flora, C.B.; Flora, J.L. Rural Communities: Legacy and Change, 3rd ed.; Westview Press: Boulder, CO, USA, 2008.

16. Emery, M.; Flora, C. Spiraling-Up: Mapping community transformation with Community Captials Framework. Community Dev. J. 2006, 37, 19-35. [CrossRef]

17. Phillips, R. Artful Business: Using the Arts for Community Economic Development. Community Dev. J. 2004, 39, 112-122. [CrossRef]

18. Bunting, T.E.; Mitchell, C.A. Artists in rural locales: Market access, landscape appeal and economic exigency. Can. Geogr. 2001, 45, 268-284. [CrossRef] 
19. Wojan, T.; Lambert, D.M.; McGranahan, D.A. Emoting with their feet: Bohemian attraction to creative milieu. J. Econ. Geogr. 2007, 7, 711-736. [CrossRef]

20. Florida, R. Cities and the creative class. City Community 2003, 2, 3-19. [CrossRef]

21. Sardu, C.; Mereu, A.; Sotgiu, A.; Contu, P. A bottom-up art event gave birth to a process of community empowerment in an Italian village. Glob. Health Promot. 2012, 19, 5-13. [CrossRef] [PubMed]

22. Stern, M.J.; Seifert, S.C. Community Revitalization and the Arts in Philadelphia; University of Pennsylvania, Social Impact of the Arts Project: Philadelphia, PA, USA, 1998.

23. Kay, A. Art and community development: The role the arts have in regenerating communities. Community Dev. J. 2000, 35, 414-424. [CrossRef]

24. Pratt, A. The cultural industries production system: A case study of employment change in Britain, $1984-91$. Environ. Plan. 1997, 29, 1953-1974. [CrossRef]

25. Evans, G. Measure for measure: Evaluating the evidence of culture's contribution to regeneration. Urban Stud. 2005, 42, 959-983. [CrossRef]

26. Holland, R.; Vail, J. Place imprinting and the arts: A case study of the Amber Collective. Local Econ. 2015, 30, 173-190. [CrossRef]

27. Zukin, S. Loft Living: Culture and Capital in Urban Change; John Hopkins University Press: Baltimore, MD, USA, 1982.

28. Chapple, K.; Jackson, S. Neighborhoods, and Social Practices: Towards an integrated epistemology of community arts. J. Plan. Educ. Res. 2010, 29, 478-490. [CrossRef]

29. Markusen, A.; Gadwa, A. Creative Placemaking; National Endowment for the Arts: Washington, DC, USA, 2010.

30. Grodach, C. Art Spaces in Community and Economic Development: Connections to Neighborhoods, Artists, and the Cultural Economy. J. Plan. Educ. Res. 2011, 31, 74-85. [CrossRef]

31. Whitt, J.A. Mozart in the metropolis: The arts coalition and the urban growth machine. Urban Aff. Q. 1987, 23, 15-36. [CrossRef]

32. Jacobson, T.; Madrigal, L.C.; Williams, R.; Terpstra, A.; Alvin, L.; Simpson, H.; Hendrickson, H.; Wakeham, T.; Oikarinen, L.; Winkler, R. Calumet's Community Capitals: An Assessment of First Fridays Art Tours; Professional Report Presented to the Calumet Community; Michigan Technological University: Houghton, MI, USA, 2013.

33. Beaulieu, L.J. Promoting Community Vitality E Sustainability: The Community Capitals Framework; Purdue University Center for Regional Development: West Lafayette, IN, USA, 2014.

34. Homer, C.G.; Dewitz, J.A.; Yang, L.; Jin, S.; Danielson, P.; Xian, G.; Coulston, J.; Herold, N.D.; Wickham, J.D.; Megown, K. Completion of the 2011 National Land Cover Database for the conterminous United States-Representing a decade of land cover change information. Photogramm. Eng. Rem. Sens. 2015, 81, 345-354.

35. Lankton, L. Cradle to Grave: Life, Work, and Death at the Lake Superior Copper Mines; Oxford University Press: Oxford, UK, 1993.

36. US Census Bureau. TIGER/Line Shapefiles. 2013. Available online: https://www.census.gov/ geo/maps-data/data/tiger.html (accessed on 7 July 2014).

37. ESRI. Data and Maps, ArcGIS 10.1, USA. Layers include hydro, parks, and highways. Source: Tele Atlas.

38. Minnesota Population Center. National Historical Geographic Information System: Version 2.0; University of Minnesota: Minneapolis, MN, USA, 2011; Available online: www.nhgis.org (accessed on 7 July 2015).

39. Pompeani, D.P.; Abbott, M.B.; Steinman, B.A.; Bain, D.J. Lake sediments record prehistoric lead pollution related to early copper production in North America. Environ. Sci. Technol. 2013, 47, 5545-5552. [CrossRef] [PubMed]

40. Nickerson, C.; Ebel, R.; Borchers, A.; Carriazo, F. Major Uses of Land in the United States; Economic Information Bulletin No. 89; United States Department of Agriculture, Economic Research Service: Washington, DC, USA, 2011.

41. US Census Bureau. American Community Survey, 2009-2013; Five Year Estimates. Accessed online: http:/ / factfinder.census.gov (accessed on 20 December 2015).

42. Kerfoot, W.C.; Urban, N.R.; McDonald, C.P.; Rossmann, R.; Zhang, H. Legacy mercury releases during copper mining near Lake Superior. J. Great Lakes Res. 2016, 42, 50-61. [CrossRef]

43. Van Auken, P.M. Seeing, not Participating: Viewscape fetishism in American and Norwegian rural amenity areas. Hum. Ecol. 2010, 38, 521-537. [CrossRef] 
44. Abrams, J.; Gosnell, H.; Gill, N.J.; Klepeis, P.J. Re-creating the rural, reconstructing nature: An international literature review of the environmental implications of amenity migration. Conserv. Soc. 2012, 10, 270-284. [CrossRef]

45. Kondo, M.C.; Rivera, R.; Rullman, S., Jr. Protecting the idyll but not the environment: Second homes, amenity migration and rural exlusion in Washington State. Landsc. Urban Plan. 2012, 106, 174-182. [CrossRef]

46. Kaunonen, G.; Goings, A. Community in Conflict: A working-Class History of the 1913-14 Michigan Copper Strike and the Italian Hall Tragedy; Michigan State University Press: East Lansing, MI, USA, 2013.

47. Lehto, S. Death's Door: The Truth behind the Italian Hall Disaster and the Strike of 1913, 2nd ed.; Momentum Books: Troy, MI, USA, 2013.

48. Thurner, A.W. Rebels on the Range: The Michigan Copper Miner's Strike of 1913-14; John H. Forster Press: Lake Linden, MI, USA, 1984.

49. O'Hagan, J.W. Participation in the arts in the United States. J. Cult. Econ. 1996, 20, 251-260.

50. Putnam, R.D. The prosperous community. Am. Prospect 1993, 7, 35-42.

51. Agnitsch, K.; Flora, J.; Ryan, V. Bonding and bridging social capital: The interactive effects on community action. Community Dev. J. 2006, 37, 36-51. [CrossRef]

52. Larsen, L.; Harlan, S.L.; Bolin, B.; Hackett, E.J. Bonding and Bridging: Understanding the relationship between social capital and civic action. J. Plan. Educ. Res. 2004, 24, 64-77. [CrossRef]

53. Sampson, R.J.; Morenoff, J.D.; Earls, F. Beyond social capital: Spatial dynamics of collective efficacy for children. Am. Sociol. Rev. 1999, 64, 633-660. [CrossRef]

54. Warren, M.R.; Thompson, J.P.; Saegert, S. The role of social capital in combating poverty. In Social Capital and Poor Communities; Saegert, J.P.T.S., Warren, M.R., Eds.; Russell Sage Foundation: New York, NY, USA, 2001; pp. 1-28.

55. Leonard, M. Bonding and bridging social capital: Reflections from Belfast. Sociology 2004, 38, 927-944. [CrossRef]

56. Portes, A. Social capital: Its origins and applications in modern sociology. In Knowledge and Social Capital; Lesser, E.L., Ed.; Butterworth-Heinemann: Boston, MA, USA, 2000; pp. $43-67$.

57. Narayan, D. Bonds and bridges: Social capital and poverty. In Social Capital and Economic Development: Well-Being in Developing Countries; Edward Elgar: Northampton, MA, USA, 2002; pp. 58-81.

58. Oldenburg, R. The Great Good Place: Cafés, Coffee Shops, Community Centers, Beauty Parlors, General Stores, Bars, Hangouts, and How They Get You through the Day; Marlowe \& Company: New York, NY, USA, 1999.

59. Granovetter, M.S. The Strength of Weak Ties. Am. J. Sociol. 1973, 78, 1360-1380. [CrossRef]

60. Calumet Township. Voter Turnout 11/04/2012. 2012, State General Election.

61. See, S.F. Keweenaw national historical park: Heritage partnerships in an industrial landscape. In Industrial Heritage and Archeology; Michigan Technological University: Houghton, MI, USA, 2013.

62. Freudenburg, W.R.; Frickel, S.; Gramling, R. Beyond the Nature/Society Divide: Learning to think about a mountain. Sociol. Forum 1995, 10, 361-392. [CrossRef]

63. Rybczynski, W.; Linneman, P.D. How to save our shrinking cities. Public Interest 1999, 135, 30-44.

64. Schilling, C.; Logan, J. Greening the rust belt: A green infrastructure model for right-sizing America's shrinking cities. J. Am. Plan. Assoc. 2008, 74, 451-466. [CrossRef]

65. Fey, S.; Bregendahl, C.; Flora, C. The Measurement of Community Capitals through Research: A Study Conducted for the Claude Worthington Benedum Foundation by the North Central Regional Center for Rural Development. Online J. Rural Res. Policy 2006, 1, Article 1. [CrossRef]

(C) 2016 by the authors; licensee MDPI, Basel, Switzerland. This article is an open access article distributed under the terms and conditions of the Creative Commons by Attribution (CC-BY) license (http://creativecommons.org/licenses/by/4.0/). 